\title{
Introduction
}

\section{Power and Influence in the Global Refugee Regime}

\author{
JAMES MILNER
}

$\mathrm{U}$ nderstanding the politics of the global refugee regime has been an important area of research in refugee and forced migration studies for nearly three decades. ${ }^{1}$ A specific focus of this work has been the challenge of fostering the various forms of international cooperation necessary for the regime to fulfill its core functions, detailed in the 1950 Statute of the Office of the United Nations High Commissioner for Refugees (UNHCR) as ensuring protection for refugees and finding a solution to their plight. ${ }^{2}$ Given the regime's demonstrated inability to predictably secure this cooperation and fulfil these functions, however, there has been a sustained interest in the role that politics and interests play in either constraining the regime, ${ }^{3}$ or, more recently, in expanding the scope and functioning of the regime. ${ }^{4}$

While this literature has made significant contributions, it is striking that there has been limited overt and systematic engagement with notions of power in the global refugee regime. $5^{5}$ Echoing the observation of Thucydides that "the strong do what they have the power to do and the weak accept what they have to accept," 6 this limited attention to power may stem from a concern that engaging with the interests of the powerful within the regime may legitimize the actions of such actors and undermine the functioning and legitimacy of the regime itself. There have also been concerns that discussions of power may stray from the analytical to the editorial, prompting some, like Chimni, to note that "what I am propounding here is not a conspiracy theory" but instead that "refugees are pawns and not concerns, and that human rights violations are often used to justify violence and the naked exercise of power."7 Moreover, where the role of power within the regime has been examined, ${ }^{8}$ power has arguably been conceptualized in a narrow sense, pointing to the need to develop a conceptualization of power that brings these diverse efforts into closer conversation while providing the basis for future research.

Regardless of one's views on the ways that power should be used within the global refugee regime, it is important for refugee and forced migration studies to develop a more systematic and comprehensive understanding of the sources and functioning of power in the regime. To paraphrase Lukes, there is a common importance in paying closer attention to power, whether that attention is motivated by a desire to "study, acquire, maintain, increase, reduce or destroy it."' In this way, it is important for our understanding of the politics of the global refugee regime to be complemented by a more systematic and rigorous understanding of power. While a range of actors seek influence, ${ }^{10}$ how do we understand the factors that determine their ability to demonstrate power within the regime? Who has power? When? Under what circumstances? What are the various forms of power? While important insights have been gained on the exercise of influence in situation-specific and high-profile initiatives, ${ }^{11}$ how can we understand and observe the functioning of power in the day-to-day practice of the regime? The answers to these questions will have important implications for theory and practice, within the global refugee regime and beyond.

These questions provided the focus for a workshop hosted at Carleton University in Ottawa, Canada, in late September $2015 .{ }^{12}$ It was a time when the global media focused on events unfolding in Europe, which served as but the latest 
example of the global refugee regime's apparent inability to ensure predictable protection for refugees and a timely solution to their plight. More than thirty representatives of the research, policy, and practitioner communities discussed papers that examined the range of actors and interests that influence outcomes in the global refugee regime, including states in the Global North and South, international organizations, and non-governmental organizations (NGOs). The articles that form this special issue were first presented at the workshop. Together, they seek to offer new perspectives on the expressions and experiences of power by diverse institutional actors within the global refugee regime and to encourage future research on these tensions and themes.

An earlier version of the article by Milner and Wojnarowicz served as a background paper for the workshop, providing a framework understanding of power that was then used as a common point of reference throughout the workshop. Drawing from the work of Barnett and Duvall, ${ }^{13}$ Milner and Wojnarowicz consider the diverse forms that power may take within the global refugee regime, and how such a disaggregated understanding of power facilitates dialogue between various theoretical conceptualizations of power. They argue that these diverse forms and expressions of power may function and be experienced differently in various contexts or "scales" of the regime, ${ }^{14}$ and that a more nuanced understanding of power could usefully open new areas of enquiry into the functioning of the global refugee regime.

In response to this framework, articles in this special issue examine the expressions, experiences, and understandings of power by a range of institutional actors within the global refugee regime, particularly states and international organizations. This is not to suggest that other actors in the regime are to be excluded from a more critical and systematic understanding of power. As highlighted by presentations at the Carleton University workshop, other actors play important roles in the functioning of the global refugee regime, and their relationship to power must equally be understood. For example, a presentation by Alexander Betts highlighted how our understanding of the power and influence of diaspora groups and refugee communities needs to be more fully incorporated into our understanding of the power exhibited by other actors. ${ }^{15}$ Likewise, a panel discussion with representatives from operational and advocacy NGos illustrated how the power that might derive from the moral and expert authority of NGOs can often be constrained by the nature of the relationships between NGOs, states, and international organizations.

While future research could usefully develop these and other dimensions of the functioning of power, this special issue begins with contributions that examine how states express and experience power in the global refugee regime.
International relations scholarship presumes that while states are not the only actor in the international system, they are arguably the most powerful. This may be especially true in the context of the global refugee regime, as UNHCR is reliant on states, both for the voluntary contribution of funds and access to their territory to pursue its work, but the contributions to this special issue suggest that the relationship is much more nuanced. Martin and Ferris examine the United States and the evolution of its role as the state that is presumed to have the most power in the global refugee regime, given that it is the single largest donor to UNHCR and resettles more refugees per year than all other countries in the world combined. As argued by Martin and Ferris, however, the foundations of us engagement in the global refugee regime are much more complex, as are the combination of factors that have historically resulted in the United States being either engaged or withdrawn from the refugee regime. Recent events in the United States, especially suggestions that a new administration may significantly revisit its role within the regime, further highlight the relevance of the argument by Martin and Ferris, and encourage readers to consider us engagement in global refugee issues within a broader historical context.

Next, contributions by Kneebone and Samaddar examine states that may be understood to have shifting power in the global refugee regime. Kneebone considers the case of Australia, especially Australia's effort to exert influence over other states in the Asia-Pacific as it pursues a domestic refugee policy aimed at preventing the arrival of asylum seekers by boat. Kneebone explains that while Australia's relations with many of its Asia-Pacific neighbours is asymmetrical, its experience negotiating with Indonesia illustrates that it is not a regional hegemon. Instead, Kneebone argues that the lack of an institutional framework and normative coherence in its approach constrain Australia's ability to impose refugee policy on the region. Samaddar's reflection on India's approach to refugees reveals how the functioning of power has been nuanced by understandings of responsibility. While India has not signed the 1951 Convention relating to the Status of Refugees, Samaddar details how the country's long history as a refugee-hosting state, indeed from the time of Partition, has nonetheless demonstrated consistent elements of protection that challenge simplistic understandings of the consequences of state power on the periphery of the international system.

The special issue includes two contributions that examine the case of Canada. The article by Molly and Madokoro draws from a unique personal account of the evolution of Canada's refugee resettlement program from the 1950 s to the establishment of the private sponsorship program in the 1980s. By tracing the tensions between domestic and international 
drivers, along with the role of individuals within bureaucracies, Molloy and Madokoro provide important new insight on the long origins of this unique approach to refugee resettlement and combination of factors that have resulted in lasting changes in state policy. Grayson and Audet provide a compelling analysis of another aspect of Canadian engagement in the global refugee regime: financial contributions to UNHCR, which doubled between 2006 and 2013, ranking Canada among the top ten donors to UNHCR. By tracing the relationship between the practice of earmarking these contributions in particular ways, and by considering the alignment of these contributions with Canadian foreign policy and development priorities and the ability of these contributions to influence the actions of UNHCR, Grayson and Audet lay a useful foundation for future empirical research on the functioning of financial contributions as a mechanism of power and influence in the global refugee regime.

The special issue then turns to the power and influence of international organizations, specifically UNHCR and the International Organization for Migration (IOM). Loescher's contribution examines the early history of UNHCR to understand how the organization worked to establish a degree of autonomy from states. As outlined by Loescher, UNHCR began its work in the early 1950 s with very few sources of power. By tracing the decisions of early high commissioners, however, Loescher illustrates how individuals within UNHCR were able to identify opportunities for the organization's mandate and autonomy to be enlarged. While he recognizes the differences between the operational context faced by UNHCR in the 1950 s and today, Loescher highlights the many enduring lessons and implications of this early period for the future evolution of UNHCR, and how the history of the organization should not be forgotten.

This examination of the evolution of UNHCR is continued in the contribution by Crisp, which provides a candid insider's analysis of the origins and evolution of one of UNHCR's most controversial policies: the protection of refugees in urban contexts. Crisp outlines the factors that accounted for the emphasis of the 1999 policy, which limited the rights of refugees in urban spaces, before detailing how the actions and interests of a range of actors ultimately contributed to the revision of the policy by 2009 , resulting in a policy that emphasized the rights of refugees to be protected in urban spaces. Crisp's systematic analysis not only provides significant insight into the means through which a particular UNHCR policy was formulated, critiqued, and revised, but serves as a template for a whole new area of research into the making and remaking of global refugee policy.

Finally, Bradley's analysis of the expanding role of Iом within the global forced-migration regime makes an important contribution to our understanding of the uses of the forms of power suggested by Barnett and Duvall and the changing contours of the global refugee regime itself. By tracing the dramatic evolution and expansion of IOM in recent years, Bradley illustrates how the organization has not been constrained by its lack of a formal mandate to engage in protection. Instead, she examines how Iом has been an entrepreneur with an ability to rapidly adapt to new contexts and demands from states, ultimately establishing itself as a leading global actor in responding to new forms of displacement, especially in the context of natural disasters. In so doing, Bradley argues that Iом has not only demonstrated its particular ability to employ diverse forms of power, but has arguably been able to stretch the regime to the extent that we are left to question if it is a global refugee or forced migration regime.

Together, the contributions to this special issue offer new perspectives on the significance and functioning of power in the global refugee regime. But they do not claim to offer a comprehensive treatment of the issue. Instead, they together illustrate the complexity of power its diverse forms, the perils of excluding understandings of power from our study of the global refugee regime, and the significant need for sustained future research in this area.

\section{Notes}

1 See, for example, Alexander Betts, Protection by Persuasion: International Cooperation in the Refugee Regime (Ithaca, NY: Cornell University Press, 2009); Alexander Betts, Gil Loescher, and James Milner, UNHCR: The Politics and Practice of Refugee Protection, 2nd ed. (Abingdon, va: Routledge, 2012); Jennifer Hyndman, Managing Displacement: Refugees and the Politics of Humanitarianism (Minneapolis: University of Minnesota Press, 20oo); Gil Loescher, Beyond Charity: International Cooperation and the Global Refugee Crisis (Oxford: Oxford University Press, 1993); and Aristide Zolberg, Astri Suhrke, and Sergio Aguayo, Escape from Violence: Conflict and the Refugee Crisis in the Developing World (Oxford: Oxford University Press, 1989).

2 See United Nations General Assembly (UNGA), Resolution 428(V), "Annex: Statute of the Office of the United Nations High Commissioner for Refugees," 14 December 1950, para. 1.

3 See Jennifer Hyndman and Wenona Giles, "Waiting for What? The Feminization of Asylum in Protracted Situations," Gender, Place and Culture 18, no. 3 (2011): 361-79; Susan Kneebone and Felicity Rawlings-Sanaei, eds., New Regionalism and Asylum Seekers: Challenges Ahead (Oxford: Berghahn Books, 2009); and James Milner, Refugees, the State and the Politics of Asylum in Africa (Basingstoke, UK: Palgrave Macmillan, 2009).

4 See Alexander Betts, Survival Migration: Failed Governance and the Crisis of Displacement (Ithaca, NY: Cornell 
University Press, 2013); Anna Lindley, ed., Crisis and Migration: Critical Perspectives (Abingdon, vA: Routledge, 2014); and Susan Martin, Sanjula Weerasinghe, and Abbie Taylor, eds., Humanitarian Crises and Migration: Causes, Consequences and Responses (New York: Routledge, 2014).

5 This stands in important contrast with the rich literature that examines how expressions of power are experienced, resisted, and contested by a range of actors, including refugees. See Milner and Wojnarowicz in this issue.

6 Thucydides, History of the Peloponnesian War, trans. Rex Warner (Harmondsworth, UK: Penguin, 1972), 402.

7 B.S. Chimni, "The Geopolitics of Asylum: A View from the South," Journal of Refugee Studies 11, no. 4 (1998): 371.

8 See Betts, Protection by Persuasion; and Randy Lippert, "Governing Refugees: The Relevance of Governmentality to Understanding the International Refugee Regime," Alternatives: Global, Local, Political 24, no. 3 (1999): 295-328.

9 Steven Lukes, Power (New York: New York University Press, 1986), 1.

10 For example, one of Canada's stated objectives is to "influence the international migration and integration policy agenda." Citizenship and Immigration Canada pursues this objective by "developing and promoting, together with other public policy sectors, Canada's position on international migration, integration, and refugee protection issues and through participation in multilateral, regional and bilateral forums." See Citizenship and Immigration Canada "Program Activity 4.3: Canada's Role in International Migration and Protection," Strategic Outcomes and Program Activity Architecture (Ottawa: Citizenship and Immigration Canada, 2011).

11 See Betts, Protection by Persuasion.

12 Funding for this workshop was generously provided by the Social Sciences and Humanities Research Council of Canada, the Refugee Research Network, the Migration and Diaspora Studies Initiative, and Carleton University.

13 See Michael Barnett and Raymond Duvall, eds., Power in Global Governance (Cambridge: Cambridge University Press, 2005).

14 See Jennifer Hyndman, "Mind the Gap: Bridging Feminist and Political Geography through Geopolitics," Political Geography 23 (2004): 307-22.

15 This presentation was not developed into an article for this special issue, as the argument is included in other recent publications. See Alexander Betts and Will Jones, Mobilizing the Diaspora: How Refugees Challenge Authoritarianism (Cambridge: Cambridge University Press, 2016); and Alexander Betts, Louise Bloom, Josiah Kaplan, and Naohiko Omata, Refugee Economies: Forced Displacement and Development (Oxford: Oxford University Press, 2016).

James Milner is associate professor of political science at Carleton University, Ottawa. The author may be contacted at james.milner@carleton.ca. 